\title{
NOX2-DEPENDENT NEUROINFLAMMATION IN AN EAE MODEL OF MULTIPLE SCLEROSIS
}

Background: Multiple sclerosis (MS) is an inflammatory disease of the CNS, focal inflammatory infiltrates and axonal damage. Oxidative stress has been linked to MS pathology. Previous studies have suggested the involvement of NADPH oxidase 2 (Nox2), an enzyme that catalyzes the reduction of oxygen to produce reactive oxygen species, in the MS pathogenesis. The mechanisms of Nox2 activation on MS are unknown. The purpose of this study was to investigate the effect of Nox2 deletion on experimental autoimmune encephalomyelitis (EAE) onset and severity, on astrocyte activation as well as on pro-inflammatory and anti-inflammatory cytokine induction in striatum and motor cortex. Methodology: Subcutaneous injection of MOG35-55 emulsified with complete Freund's adjuvant was used to evaluate the effect of Nox2 depletion on EAE-induced encephalopathy. Striatum and motor cortices were isolated and evaluated by immunoblotting and RT-PCR. Results: Nox2 deletion resulted in clinical improvement of the disease and prevented astrocyte activation following EAE induction. Nox2 deletion prevented EAE-induced induction of pro-inflammatory cytokines and stimulated the expression of the anti-inflammatory cytokines IL-4 and IL-10. Conclusions: Our data suggest that Nox2 is involved on the EAE pathogenesis. IL-4 and IL-10 are likely to be involved on the protective mechanism observed following Nox2 deletion.

Keywords

Multiple sclerosist • NADPH oxidaset • astrocytest • cytokine

\section{Abbreviations}

$\begin{array}{ll}\text { CFA } & \text { Complete Freund's adjuvant } \\ \text { CNS } & \text { Central nervous system } \\ \text { EAE } & \text { Experimental autoimmune } \\ & \text { encephalomyelitis } \\ \text { MOG } & \text { Myelin oligodendrocyte glycoprotein } \\ \text { MS } & \text { Multiple sclerosis } \\ \text { NO } & \text { Nitric oxide } \\ \text { Nox2 } & \text { NADPH oxidase } 2 \\ \text { Noxes } & \text { NADPH oxidases } \\ \text { PBS } & \text { Phosphate buffered saline } \\ \text { ROS } & \text { Reactive oxygen species }\end{array}$

\section{Introduction}

Multiple sclerosis (MS) is an autoimmune inflammatory disease of the central nervous system (CNS), characterized by demyelination, focal inflammatory infiltrates and axonal damage $[1,2]$. Several brain areas are affected, including but not limited to the cerebellum, brainstem, optic nerves and spinal cord [2]. Studies revealed atrophy of the temporal and frontal cortical areas, as well as demyelination in the thalamus, basal ganglia, hypothalamus, hippocampus, cerebellum and neocortex [3] MS clinical symptoms include sensory or motor impairment, ataxia, spasticity, fatigue, and cognitive impairment [3].

Experimental autoimmune encephalomyelitis (EAE) is the most commonly used experimental model for MS induction [4]. EAE can be induced in rodents by immunization with myelin constituents, such as myelin basic protein, myelin oligodendrocyte glycoprotein (MOG) and proteolipid protein [5]. A subcutaneous injection of the antigen in complete Freund's adjuvant (CFA) followed by two intraperitoneal injections of pertussis toxin (on the day of immunization and two days later) induces activation of myelin-specific $T$ lymphocytes in the periphery and its migration into the CNS where T cells are reactivated by antigenpresenting cells leading to a subsequent inflammatory cascade and, eventually, demyelination and axonal degeneration [6].

Following EAE induction, activated macrophages and microglial cells produce multiple mediators of tissue damage, including proteases, nitric oxide (NO) and reactive oxygen species (ROS), resulting in neurodegeneration
Katherine G. Ravelli', Graziella D. Santos' Nilton B. dos Santos', Carolina D. Munhoz ${ }^{2}$

Deborah Azzi-Nogueira' Ana Carolina Campos ${ }^{4}$ Rosana L. Pagano ${ }^{4}$,

Luiz R. Britto', Marina S. Hernandes ${ }^{3 *}$

'Department of Physiology and Biophysics, University of São Paulo, São Paulo, Brazil

2Department of Pharmacology, University of São Paulo, São Paulo, Brazil, ${ }^{3}$ Division of Cardiology, Department of Medicine Emory University, Atlanta, GA, United States ${ }^{4}$ Laboratory of Neuroscience,

Hospital Sirio-Libanes, Sao Paulo, SP, Brazil

Received 20 July 2018

accepted 17 January 2019

*E-mail:mshern2@emory.edu

(cc)BY 92019 Katherine G. Ravelli et al., published by De Gruyter.

This work is licensed under the Creative Commons Attribution 4.0 Public License.

[7]. ROS generated by macrophages appear to be involved in demyelination and axonal damage induced by EAE [8]. ROS derived from mononuclear cells mediate oxidation of total DNA as well as mitochondrial DNA in patients with MS $[9,10]$. Moreover, evidence of lipid peroxidation has been described in exhaled breath samples of MS patients [11]. Additional studies have shown decreased levels of antioxidant enzymes in blood and cerebrospinal fluid of MS patients [12, 13].

NADPH oxidases (Noxes) are a family of enzymes able to catalyze the production of ROS. The prototypical Nox, the Nox 2 isoform, is composed of three cytosolic components (p47 $7^{\text {phox }}, p 67^{\text {phox }}$ e $p 40^{\text {phox }}$ ) and two membrane subunits (gp91 $1^{\text {phox }}$ e p22 $2^{\text {phox }}$ ). After stimulation, p47 phox is phosphorylated and the cytosolic components translocate to the membrane, where they associate with the membrane components, forming a functional Nox complex which utilizes the reduction equivalents of NADPH to reduce oxygen to superoxide [14].

Nox inhibition by apocynin, a nonspecific pharmacological Nox2 inhibitor, reduced profoundly the clinical features and 
neuropathological changes associated with EAE in MOG35-55-induced EAE model [15]. Moreover, an in vitro study demonstrated that the treatment with NADPH oxidase inhibitors (diphenyleneiodonium or apocynin) prevented myelin phagocytosis by peritoneal macrophages [8]. Furthermore, Nox2 mRNA expression was found to be upregulated in spinal cord in both relapsing-remitting and chronic models of EAE [16]. In MS patients, Nox2 was shown to be upregulated in activated microglia found in demyelinating and chronic MSlesions in brain tissue [17]. In a different study, it has been shown that microglial cells express Nox2 in preactive MS lesions, suggesting that microglial Nox2-derived ROS might be involved in the pathogenesis of MS [18]. A study using p47 phox knockout mice showed that Noxes inhibit the macrophage-derived NO, a strong inhibitor of T cell proliferation, which could be involved in the resistance of these animals to active EAE induction [19].

Although it has been previously demonstrated that EAE increases Nox activity in the brain and spinal cord [20], the mechanisms of Nox2 activation on the $\mathrm{MOG}_{35-55}$ induced EAE remain largely unknown. Here, we investigated the effects of EAE induction on the protein expression of a Nox2 subunit, the effect of Nox2 deletion on EAE onset and severity, astrocyte activation as well as on pro inflammatory and anti-inflammatory cytokines induction in brain structures commonly affected by EAE. Striatum and motor cortex, brain regions involved in motor control, were our choices of study.

\section{Material and Methods}

\section{Animals}

Female ten week-old gp9 $1^{\text {phox-/- mice (obtained }}$ from Jackson Laboratories, Maine, USA) $(n=50)$ in the $\mathrm{C} 57 \mathrm{BL} / 6$ background were used for this study. Controls for gp9 $91^{\text {phox-l- }}$ mice were C57BL/6 mice (gp91 $1^{\text {phoxt/++}}$ mice - obtained from Jackson Laboratories, Maine, USA, $n=50$ ). Mice had free access to food and water and were maintained on a 12:12 h light-dark cycle. All protocols were approved by the Ethics Committee for Animal Research of the University of Sao Paulo and experimental procedures were performed in accordance with the guidelines of the Brazilian
College for Animal Experimentation (COBEA) and the animal care guidelines of the National Institutes of Health (NIH).

\section{EAE induction and behavioral score} Mice were given a flank subcutaneous injection of $150 \mu \mathrm{g}$ of MOG $_{35-55}$ emulsified with complete Freund's adjuvant (MOG/CFA) which contained $0.3 \mathrm{mg}$ of heat-inactivated Mycobacterium tuberculosis (H37RA; Difco Laboratories). Each animal also received pertussis toxin (200ng i.p; List Biological Laboratories) on day 0 and day 2 post-immunization. Mice were monitored daily up to 20 days for signs of disease. Control mice were treated with PBS emulsified with CFA without antigen. The EAE clinical score was determined based on the following scale: 0 , no disease; 1 , limp tail or isolated weakness of gait without limp tail; 2, partial hind limb paralysis; 3 , total hind limb or partial hind and front limb paralysis; 4, total hind leg and partial front leg paralysis; 5, moribund or dead animal. The animals were euthanized for analysis 20 days following EAE induction. All behavior testing was performed in a blinded fashion. Different groups of mice were used for immunohistochemistry, immunoblotting and real-time PCR assays.

\section{Immunohistochemistry}

Mice were deeply anesthetized (ketamine, $100 \mathrm{mg} / \mathrm{kg}$ of body weight and xylazine, 16 $\mathrm{mg} / \mathrm{kg}$ of body weight, i.m.) and perfused transcardially with $0.1 \mathrm{M}$ phosphate buffered saline (PBS) followed by $4 \%$ paraformaldehyde in $0.1 \mathrm{M}$ sodium phosphate buffer ( $\mathrm{PB}, \mathrm{pH} 7.4$ ). Brains were then removed and post-fixed for $4 \mathrm{~h}$ in the same fixative and cryoprotected in a $30 \%$ sucrose solution for at least $48 \mathrm{~h}$ at $4^{\circ} \mathrm{C}$. Coronal brain sections $(30 \mu \mathrm{m})$ were obtained on a sliding microtome and stored at $4^{\circ} \mathrm{C}$. Freefloating sections were incubated for 12-16 $\mathrm{h}$ using an antibody against p47phox (Chemicon, USA). Samples were then incubated with a secondary antibody in phosphate buffered saline (PBS) with $0.3 \%$ TritonX-100 for $2 \mathrm{~h}$ at room temperature. After washing, samples were incubated with an avidin-biotinperoxidase complex ( $A B C$ Elite kit, Vector Labs., Burlingame, CA, USA) for $2 \mathrm{~h}$ at room temperature. Labeling was developed with
0.05\% diaminobenzidine tetrahydrochloride. The sections were mounted on glass slides, dehydrated and coverslipped using Permount (Fisher, Pittsburg, PA, USA). The material was analyzed on a light microscope and digital images were acquired. For the motor cortex, the analysis was focused on an intermediate area of the primary motor cortex, between 1 and $2 \mathrm{~mm}$ rostral to the bregma. Regarding the striatum, the analysis was performed in the rostral striatum (between 1 and $2 \mathrm{~mm}$ rostral to the bregma). Brain areas of interest were identified using a stereotaxic atlas and semi-quantitative image analysis was performed using ImageJ software (National Institutes of Health/USA). Immunostaining optical density was evaluated within $0.4 \mathrm{~mm}^{2}$ areas for each brain structure analyzed as previously described [21]. The resulting indexes for the groups were then compared and subjected to statistical analysis using Graphpad Prism 3.02 (GraphPad Software Inc., San Diego, CA, USA).

\section{Western blotting}

Mice were sacrificed and the regions of interest were quickly collected, frozen in liquid nitrogen, and stored at $-70{ }^{\circ} \mathrm{C}$ until use. The tissue was homogenized in extraction buffer (Tris, pH 7.4, 100 mM; sodium pyrophosphate $100 \mathrm{mM}$; sodium fluoride $100 \mathrm{mM}$; EDTA $10 \mathrm{mM}$, sodium orthovanadate $10 \mathrm{mM}$; PMSF $2 \mathrm{mM}$; aprotinin $0.01 \mathrm{mg} / \mathrm{ml}$ ) and the homogenates were centrifuged for $15 \mathrm{~min}$ at $15,300 \mathrm{xg}$ at $4^{\circ} \mathrm{C}$. The protein concentration of the supernatant was determined using the Bradford method (Bio- Rad, CA, USA). The samples were stored in sample buffer (Tris/HCl 500 mM, pH 6.8; 10\% of SDS, $0.25 \%$ of bromophenol Blue; $10 \%$ of 2-mercaptoethanol and $50 \%$ glycerol) at $-70^{\circ} \mathrm{C}$ until starting the assay. Thirty $\mu \mathrm{g}$ of protein were boiled for $5 \mathrm{~min}$, applied to acrylamide SDS gels (Bio-Rad, CA, USA) and electrophoretically transferred to nitrocellulose membranes (Millipore, Billerica, MA, USA) at $100 \mathrm{~V}$ for 90 $\mathrm{min}$. The membranes were then blocked for 1 hour at room temperature with PBS containing 0.05\% Tween-20 (TTBS) and 5\% nonfat milk and incubated overnight at $4^{\circ} \mathrm{C}$ with a monoclonal antibody anti-rabbit Gfap (1:1000; Santa Cruz Biotechnology, USA) diluted in TTBS with $1 \%$ non-fat milk. Following incubation with 
the appropriate HRP-conjugated secondary antibody, the probed proteins were developed by using a chemiluminescent kit (ECL, Amersham Biosciences, NJ, EUA). The target proteins were detected using a C-DiGit Western blot scanner (LI-COR, USA) and $\beta$-actin was used as an internal control. The quantification of band intensity was performed with ImageJ (National Institutes of Health, USA).

\section{Real- time PCR}

Tissue from the brain regions of interest was collected, homogenized in $1 \mathrm{ml}$ TRIzol (Invitrogen, Carlsbad, CA, USA) and total RNA was isolated following the manufacturer's protocol. Briefly, following one chloroform extraction step, RNA was precipitated with isopropanol and the pellet washed once in $70 \%$ ethanol. After air-drying, the RNA was resuspended in DEPC-treated water and the concentration of each sample was obtained from A260/A280 nm measurements. One microgram total RNA was reverse transcribed by using the Promega Reverse Transcription System (Madison, WI, USA). Total RNA was incubated at $70^{\circ} \mathrm{C}$ for 10 minutes. The solution was mixed with $4 \mu \mathrm{L}$ of $\mathrm{MgCl} 2(25 \mathrm{mM}), 2 \mu \mathrm{L}$ of $5 \times$ first strand buffer, $2 \mu \mathrm{L}$ of dNTP mixture (10 $\mathrm{mM}), 0.5 \mu \mathrm{l}$ of RNAsin inhibitor $(40 \mathrm{U} / \mu \mathrm{l}), 0.5 \mu \mathrm{l}$ of AMV reverse transcriptase and $1 \mu \mathrm{L}$ of oligodT primer $(0.5 \mu \mathrm{g})$. The reaction was incubated at $16^{\circ} \mathrm{C}$ for $30 \mathrm{~min}, 42^{\circ} \mathrm{C}$ for $30 \mathrm{~min}, 85^{\circ} \mathrm{C}$ for 5 min and then kept at $4^{\circ} \mathrm{C}$. qPCR was carried out with SYBR Green Real-Time Selected Master Mix (Applied Biosystems, CA, USA) following the manufacturer's protocol. The reaction mix (20 $\mu \mathrm{L}$ final volume) included the following: 2 $\mu \mathrm{L}$ diluted $\mathrm{CDNA}, 10 \mu \mathrm{L}$ of SYBR Master Mix, and $500 \mathrm{nM}$ of each primer. Amplification and PCR product detection were performed with the ABI prism 7500 real time-PCR System (Applied Biosystems, USA). PCR cycling conditions were set as follows: $50^{\circ} \mathrm{C}$ for $2 \mathrm{~min}, 95^{\circ} \mathrm{C}$ for 2 min, then 30 cycles of $95^{\circ} \mathrm{C}$ for $15 \mathrm{~s}, 60^{\circ} \mathrm{C}$ for $1 \mathrm{~min}$, and $72^{\circ} \mathrm{C}$ for $15 \mathrm{~s}$. The specificity of the SYBR $^{\circledR}$ green assay was confirmed by meltingpoint analysis. Expression data was calculated from the cycle threshold $(\mathrm{Ct})$ value using the $\Delta C t$ method for quantification [22]. Primer sequences are indicated in Table 1.

\section{Cytokine ELISAs}

IL-4, IL-6 and IL-10 levels in brain tissue were measured using specific ELISA kits according to the manufacturer's instructions (R\&D Systems).

\section{Statistical analysis}

Data are expressed as the mean \pm SEM. For individual comparisons, statistical analysis was performed using unpaired Student's $t$-test. Statistical analysis for EAE-induced changes in $\mathrm{Nox}^{+/+}$and Nox2 ${ }^{-/}$mice were performed by one-way analysis of variance (ANOVA), followed by pairwise comparisons (Tukey's HSD test). For the clinical score evaluation, a two-way ANOVA followed by a Bonferroni post hoc test was used to assess significance between $\mathrm{Nox}^{+/+}$and Nox2 ${ }^{-/}$groups. In all cases, $\mathrm{p} \leq 0.05$ was considered to be statistically significant. Statistical analyses of data were generated using GraphPad Prism, version 3.02 (GraphPad Software Inc., San Diego, CA, USA).

\section{Results}

\section{Effect of EAE on p47phox expression}

In both structures analyzed p47 phox, a Nox2 cytosolic component, was found very diffuse and with a punctuate pattern of staining. There was a statistically significant increase in the expression of $\mathrm{p} 47^{\text {phox }}$ in striatum (Figure $1 \mathrm{~A}$, $p<0.01$ ) and motor cortex (Figure 1B, $p<0.01$ ) of $\mathrm{Nox}^{+/+}$mice following EAE induction when compared to the control groups.

\section{A}

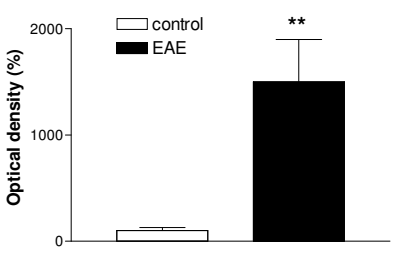

B

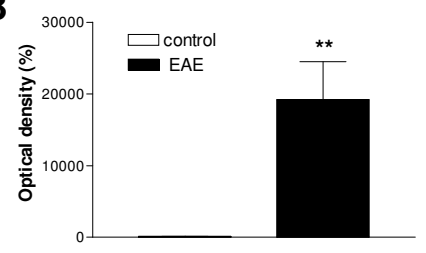

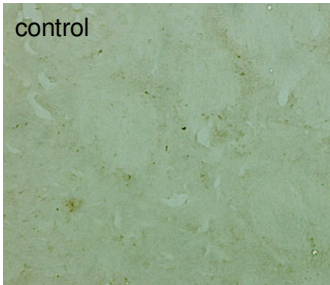
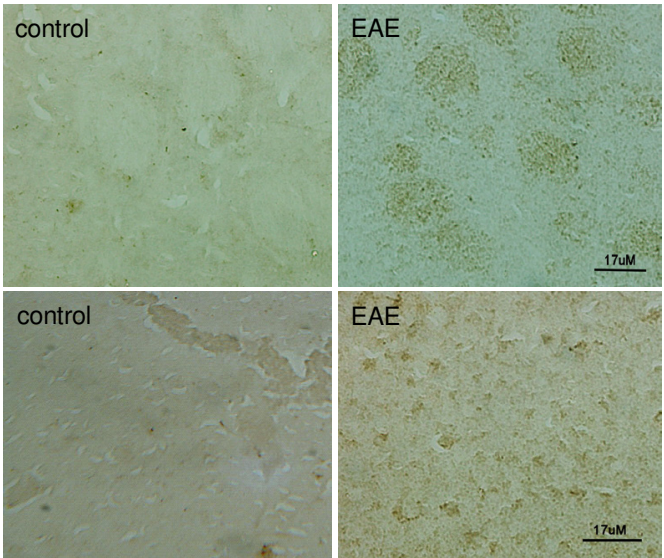

Figure 1. Effect of EAE induction on p47phox immunoreactivity in striatum (A) and motor cortex (B) of Nox $2^{+/+}$ mice. The graph depicts the mean optical density of $\mathrm{p} 47^{\mathrm{phox}}$ immunostaining. Representative digital images of p47 ${ }^{\text {phox }}$-like immunoreactivity. ${ }^{* *} \mathrm{p}<0.01$ (Student's $t$-test). $\mathrm{N}=4$. EAE: Experimental autoimmune encephalomyelitis.

Table 1: Description of primers used throughout the study to analyze the genes of interest

\begin{tabular}{|c|c|c|}
\hline Gene & Primers sequence $\left(5^{\prime}\right.$ to $\left.3^{\prime}\right)$ & Amplicon length (bp) \\
\hline $\mathrm{IL}-1 \beta$ & $\begin{array}{l}\text { FW: TGCCACCTTTTGACAGTGATG } \\
\text { RV: ATGTGCTGCTGCGAGATTTG }\end{array}$ & 136 \\
\hline MCP-1 & $\begin{array}{l}\text { FW: GGCTGGAGAGCTACAAGAGG } \\
\text { RV: CTTGGTGACAAAAACTACAGC }\end{array}$ & 69 \\
\hline IL-4 & $\begin{array}{l}\text { FW: CAGCAACGAAGAACACCACAG } \\
\text { RV: AAGCCCGAAAGAGTCTCTGC }\end{array}$ & 144 \\
\hline IL-10 & $\begin{array}{l}\text { FW: GCGCTGTCATCGATTTCTCC } \\
\text { RV: CTCTTCACCTGCTCCACTGC }\end{array}$ & 60 \\
\hline IL-6 & $\begin{array}{l}\text { FW: TCCTCTCTGCAAGAGACTTCC } \\
\text { RV:TTGTGAAGTAGGGAAGGCCG }\end{array}$ & 80 \\
\hline GAPDH & $\begin{array}{l}\text { FW: GTGCAGTGCCAGCCTCGTCC } \\
\text { RV: CAGGCGCCCAATACGGCCAA }\end{array}$ & 107 \\
\hline
\end{tabular}

IL-1ß: interleukin 1 beta; MCP-1: monocyte chemoattractant protein -1; IL-4: interleukin 4; IL-10: interleukin 10; IL-6: interleukin 6; GAPDH: glyceraldehyde 3-phosphate dehydrogenase. 
Effect of Nox2 deletion on EAE onset and severity

As shown in Figure 2, in $\mathrm{Nox}^{+/+}$mice clinical signs of EAE were first noticed at day 14 post immunization and developed a rapid worsening that peaked around day 18 and were stable until day 20 post immunization. In Nox $2^{-1-}$ mice, clinical symptoms were observed starting from day 16 and 17, and were overall less pronounced $(p<0.001$ versus daily clinical score for all days analyzed between days 15 and 20 post immunization) when compared to Nox2 ${ }^{+/+}$mice (Figure 2).

\section{Nox2 deletion abrogates GFAP} protein expression induced by EAE Western blotting was used to quantitatively evaluate GFAP protein expression in the striatum and motor cortex following $E A E$ induction. In both striatum and motor cortex, an increase in GFAP protein expression was observed in Nox $2^{+/+}$mice $(p<0.05$ and $p<0.01$, respectively), which was abrogated in $\mathrm{Nox}^{-1-}$ mice (Figure 3).

\section{Nox2 mediates proinflammatory cytokine induction following EAE}

To determine whether Nox 2 regulates cytokine induction, we first examined their mRNA and expression levels after EAE induction. Twenty days following EAE induction, IL1 $\beta$, MCP-1 and IL-6 mRNA expression were found significantly increased in both striatum (Figure $4 A ; p<0.01$; $p<0.01$ and $p<0.01$ vs control, respectively) and motor cortex (Figure 4B; $p<0.01 ; p<0.01$ and $\mathrm{p}<0.001$ vs control, respectively) of $\mathrm{Nox2}^{+/+}$ mice. Loss of Nox2 impaired EAE-induced IL1 $\beta$, MCP-1 and IL- 6 mRNA expression in both structures analyzed. Additionally IL- 6 protein levels were evaluated in the brain tissue of $\mathrm{Nox}^{+/+}$and $\mathrm{Nox}^{2-/}$ mice using ELISA. Although there was a trend toward significance between the Nox2 $2^{+/+}$EAE and the Nox2 $2^{+/+}$control groups, IL-6 protein levels were not significantly increased in the striatum of either $\mathrm{Nox}^{+/+}$ and Nox2 ${ }^{-/}$mice after EAE (Fig. 6). IL-6 protein expression was increased in the motor cortex of $\mathrm{Nox}^{+/+}$mice following EAE induction (Fig. 6; $p<0.05$ vs control); however, Nox $2^{-/-}$mice exhibited an attenuation of EAE-induced IL- 6 expression compared to $\mathrm{Nox}^{+/+}$mice after EAE induction.

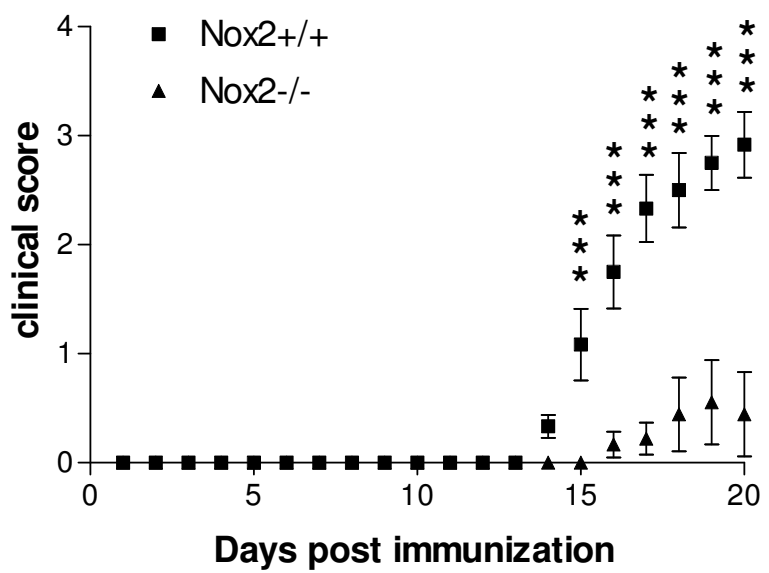

Figure 2. Effect of Nox2 deletion on EAE onset and severity. Nox2 $2^{+/+}$and Nox2 $2^{-/}$mice were monitored daily up to 20 days for signs of disease following immunization. $\mathrm{N}=6-9$. ${ }^{* * *} \mathrm{p}<0.001$ (Bonferroni's test).

A

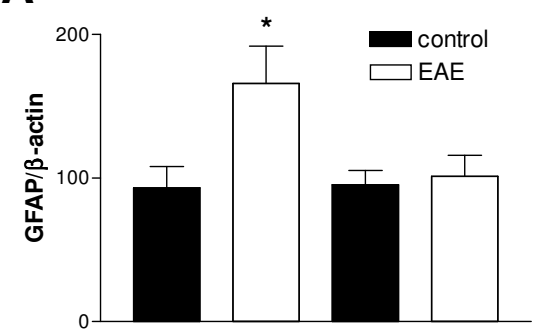

Nox2 + +/+ $-/-$

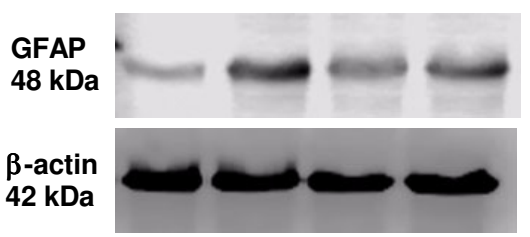

B
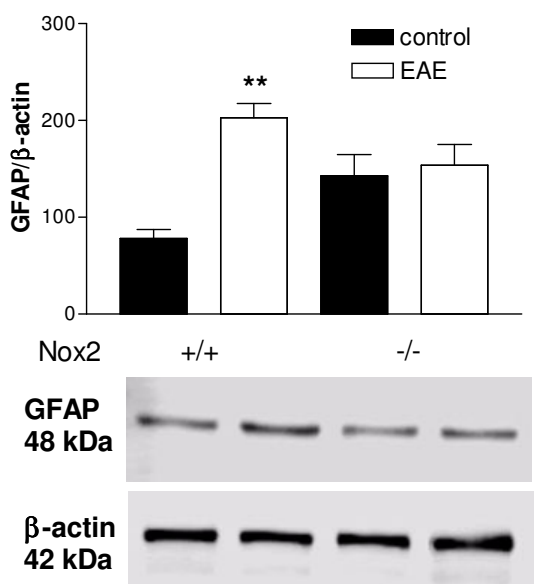

Figure 3. Effect of EAE on GFAP expression in striatum (A) and motor cortex (B) of Nox $2^{+/+}$and Nox $2^{-/-}$mice. Western blots analysis of the GFAP protein levels. The graphs represent mean ratio of GFAP densitometric data in relation to $\beta$-actin. ${ }^{*} \mathrm{p}<0.05$ and ${ }^{* *} \mathrm{p}<0.01$ vs respective control (Tukey's test). $\mathrm{N}=4-6$. EAE: Experimental autoimmune encephalomyelitis.

\section{Effect of Nox2 deletion on the}

induction of anti inflammatory cytokines following EAE

In order to determine the effect of Nox2 deletion on the mRNA expression of the anti inflammatory cytokines IL-4 and IL-10 RTPCR was performed. As shown in Figure 5 EAE induction did not increase IL-4 mRNA expression in either striatum or motor cortex of Nox2 ${ }^{+/+}$mice, however, loss of Nox 2 significantly increased EAE-induced IL-4 in both structures analyzed (Figure $5 \mathrm{~A} ; \mathrm{p}<0.05$ vs $\mathrm{Nox}^{-\%}$ control in striatum; Figure $5 \mathrm{~B} ; \mathrm{p}<0.01$ vs $\mathrm{Nox}^{-1-}$ control in motor cortex). Similarly, IL-10 was found upregulated in the striatum of Nox2 ${ }^{--}$(Figure $5 \mathrm{~A} ; \mathrm{p}<0.01$ vs $\mathrm{Nox}^{-1-}$ control) but not in $\mathrm{Nox}^{+/+}$ mice following EAE induction. Conversely, in the motor cortex EAE induction was able to increase IL-10 mRNA expression only in Nox2 ${ }^{+/+}$ (Figure 5B; $\mathrm{p}<0.05$ vs $\mathrm{Nox}^{+/+}$control) but not in Nox $2^{-/-}$mice. Additionally, IL-4 and IL-10 protein levels were evaluated in in the striatum and motor cortex of $\mathrm{Nox}^{+/+}$and $\mathrm{Nox}^{-/-}$mice using ELISAs. IL-4 induction was found below detectable levels in both structures analyzed. Corroborating the mRNA expression data, IL- 
10 protein levels were found increased in the striatum of $\mathrm{Nox}^{--}$mice after EAE but not in the motor cortex (Figure 6, $\mathrm{p}<0.05$ vs Nox2 $2^{+/+} \mathrm{EAE}$ ).

\section{Discussion}

In the present study, we present evidence to support our hypothesis that Nox2 plays an important role on the neuroinflammation induced by EAE. Our findings suggest that (1) $p 47^{\text {phox }}$ immunoreactivity is increased in striatum and motor cortex following EAE induction; (2) Nox2 deletion resulted in clinical improvement of the disease and prevented astrocyte activation as well as increased mRNA expression of proinflammatory cytokines following EAE induction (3) Nox2 deletion increased the induction of the antinflammatory cytokines IL-4 and IL-10 following EAE induction.

The human Nox2 gene is associated with MS and its expression is correlated with disease severity [23]. As noted earlier, p47 ${ }^{\text {phox }}$ is among the most important subunits regulating Nox2 activity. We found a substantial increase in p47 ${ }^{\text {phox }}$ immunoreactivity in both structures analyzed following EAE induction, suggesting the activation of Nox2 isoform. Of note, since Nox 1 is also activated by forming a complex with $\mathrm{p} 47^{\text {phox }}$ in a similar manner to Nox2 [24], we cannot rule out the possibility that $p 47^{\text {phox }}$ may also influence Nox1-specific signaling. Corroborating our results, Nox2 mRNA expression was found upregulated in spinal cord [25] and brain tissue [26] after EAE induction. Moreover, gene expression of the subunits $\mathrm{p} 47^{\text {phox }}, \mathrm{p} 67^{\text {phox }}$, and $\mathrm{gp} 91^{\text {phox }}$, were all found increased after MOG-induced EAE. The Nuclear factor-erythroid 2-related factor 2 (Nrf2), a transcription factor that regulates genetic expression of many protective antioxidant enzymes, can be responsible for this neuroinflammatory response, since all these subunits were also significantly increased in Nrf2 knockout mice compared to the WT mice following EAE induction [27].

Nox2 has been implicated in several neuropathological conditions $[26,28]$. We have recently shown that Nox 2 deletion protects mice against cognitive impairment induced by streptozotocin [28]. In the present study, Nox2

A

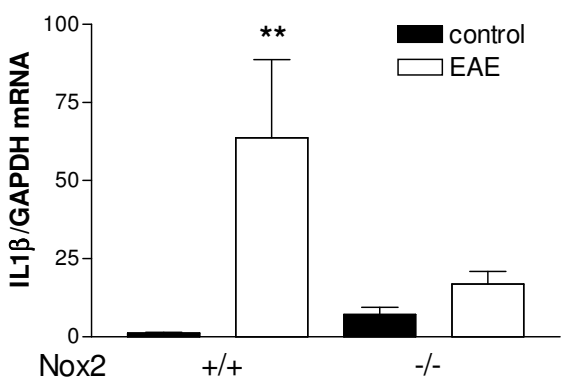

B
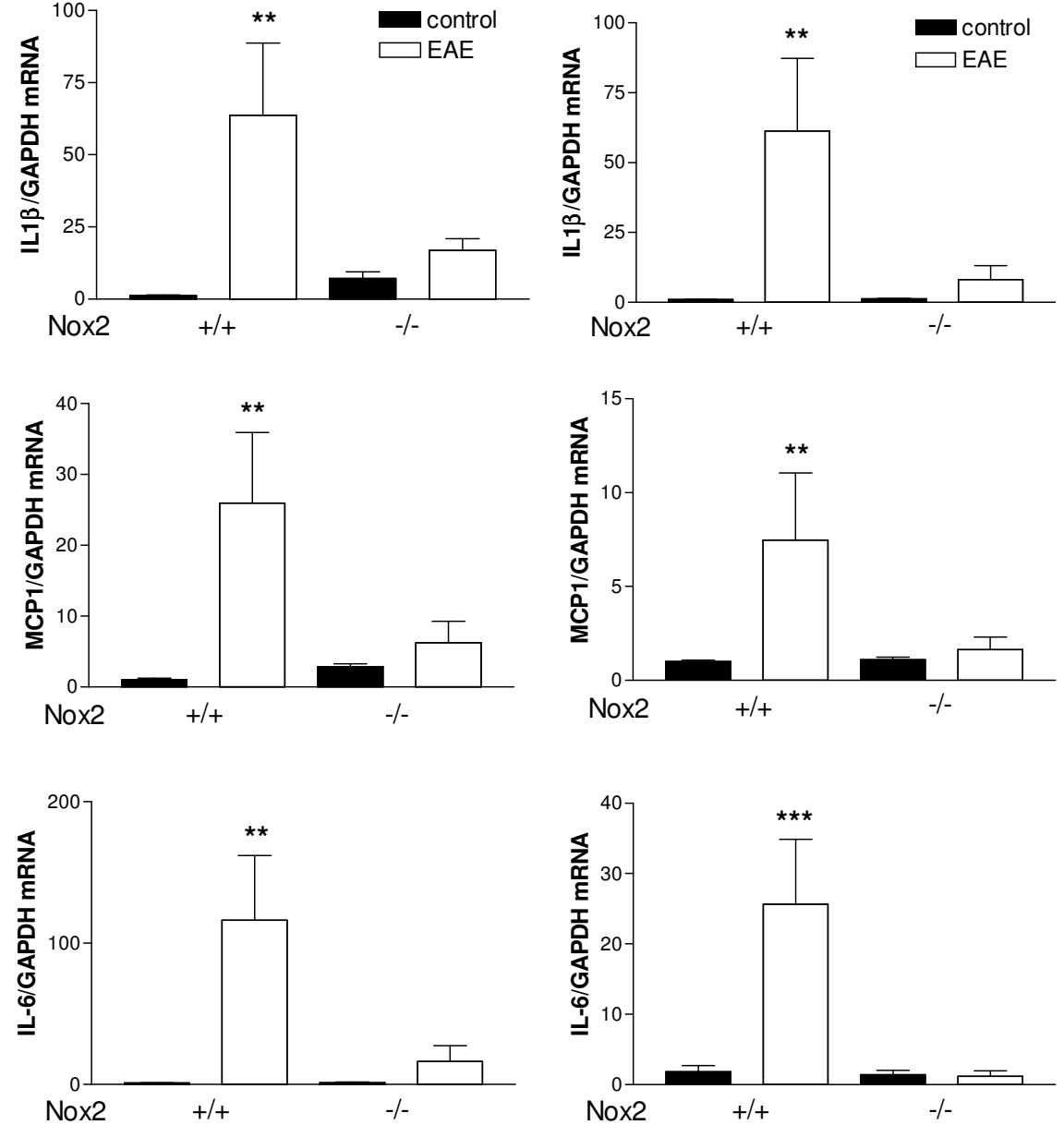

Figure 4. Effect of EAE induction on the mRNA levels of the pro-inflammatory cytokines IL-6, IL $1 \beta$ and MCP-1 in striatum (A) and motor cortex (B) of Nox $2^{+/+}$and Nox2 $2^{-/}$mice. GAPDH was used as an internal control. ${ }^{* *} \mathrm{p}<0.01$ vs respective control, ${ }^{* * *} \mathrm{p}<0.001$ vs respective control (Tukey's test). $\mathrm{N}=5-6$. EAE: Experimental autoimmune encephalomyelitis.

deletion significantly decreased clinical signs of EAE induced by the treatment with MOG35-55. In agreement with our data, Nox2 knockdown improved clinical scores, prevented body weight loss and oxidative stress-induced nitrotyrosine formation in a mouse model of EAE [29]. It has been demonstrated that Nox2 alters the pattern of proteolytic digestion. Nox2 depletion affected the ability of macrophages to process and present the I-Abimmunodominant peptide of the $\mathrm{MOG}_{35-55}$. P47 $7^{\text {phox }}$ and $9 p 91^{\text {phox }}$ deficient mice were partially protected from MOG-induced $E A E$, partially due to an ineffective reactivation of MOG-specific CD4+T cells in the CNS due to the inefficient processing of endogenous MOG to the $\mathrm{MOG}_{35-55}$ epitope by $\mathrm{Nox}^{-1-}$ macrophages [30].

Astrocytes play a critical role in MS progression. They have been shown to inhibit remyelination and axonal regeneration by releasing several cytotoxic factors and also by forming a glial scar [31]. MS patients exhibited increased expression of GFAP in MS lesions [32] and in the cerebrospinal fluid [33]. Similarly, up-regulation of GFAP has been described in the spinal cord of mice in the chronic phase of EAE induced by $\mathrm{MOG}_{35-55}$ [33]. In our study we observed that EAE induction increased GFAP expression in striatum and motor cortex. Nox2 
deletion attenuated GFAP immunoreactivity in both structures, suggesting an important role for Nox2 in mediating $\mathrm{MOG}_{35-55}$-induced astrocyte activation. Similar results have been described previously in other neurodegenerative conditions, such as Parkinson's disease [21], sepsis induced encephalopathy [34] and Alzheimer's disease [28].

The clear effect of Nox2 deletion on astrocyte activation suggested that the inflammatory response would be affected. The mRNA expression of IL-6, IL $1 \beta$ and MCP-1 was evaluated in striatum and motor cortex following EAE induction. The data indicate that the mRNA expression of all the cytokines analyzed was found significantly increased in both striatum and motor cortex of $\mathrm{Nox2}^{+/+}$mice. Importantly, in our study, Nox2 deletion inhibited EAEinduced IL-6, IL1 $\beta$ and MCP-1 mRNA expression. It has been previously demonstrated that the expression of IL- 6 is increased in macrophages and astrocytes in MS [35]. Moreover, its concentration was found elevated in serum and CSF [36]. IL- 6 blockade by the treatment with an anti-IL-6 receptor monoclonal antibody inhibited the development of EAE in mice [37]. Corroborating our data, elevated levels of IL- 6 have been described in CSF [38] and in brain structures in experimental models of MS [39]. IL$1 \beta$ has been shown to be released by monocytes, microglia, astrocytes and brain endothelial cells and it is involved in inflammatory reactions within the CNS. Similarly to IL-6, enhanced levels of IL-1 $\beta$ have been described to be increased in MS lesions [40]. Of note, the correlation between IL-6, IL-1 $\beta$ and Nox 2 was demonstrated in a study involving traumatic brain injury (TBI). TBI significantly increased mRNA levels of IL- 6 and IL$1 \beta$ in in the cortex, which was attenuated upon Nox2 knockdown [41]. Nox2 deletion has also been shown to inhibit streptozotocin-induced IL1 $\beta$ production in the hippocampus [28].

MCP-1, a monocyte chemoattractant, is produced by several immune and nonimmune cells [42]. In MS, this chemokine has been demonstrated to be released from astrocytes and macrophages and it seems to play a role in the demyelination of the CNS [43]. Increased expression of MCP-1 has been detected in astrocytes in the spinal cord following EAE induction [44]. Diphenyliodonium, a non-
A

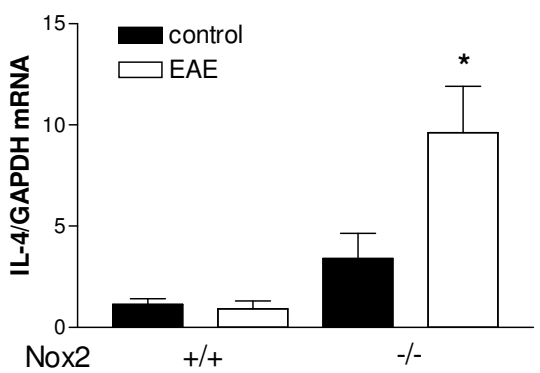

B
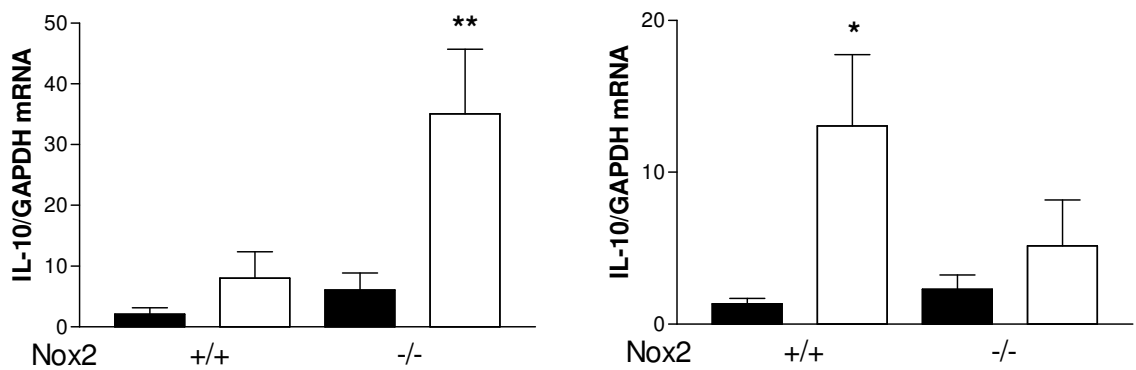

Figure 5. Effect of EAE induction on mRNA levels of the anti-inflammatory cytokines IL-4 and IL-10 in striatum (A) and motor cortex (B) of $\mathrm{Nox}^{+/+}$and Nox2 $-/$mice. GAPDH was used as an internal control. ${ }^{*} \mathrm{p}<0.05$ vs respective control, ${ }^{* *} \mathrm{p}<0.01$ vs respective control (Tukey's test). $\mathrm{N}=5-6$. EAE: Experimental autoimmune encephalomyelitis.
A
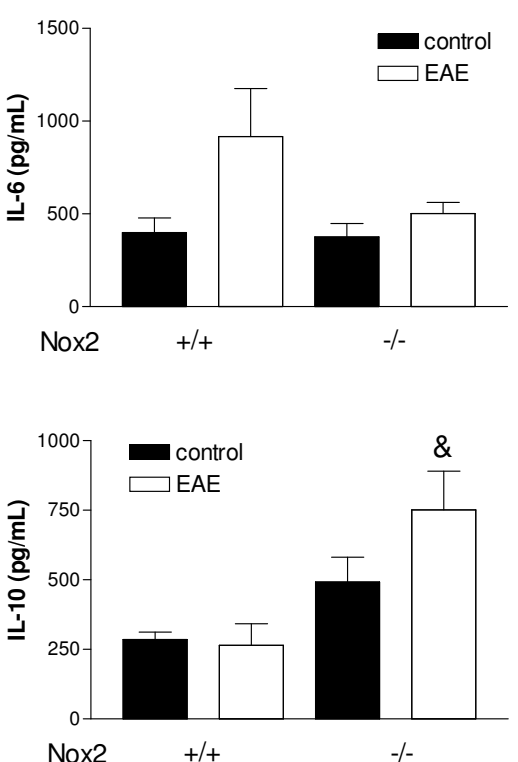

B
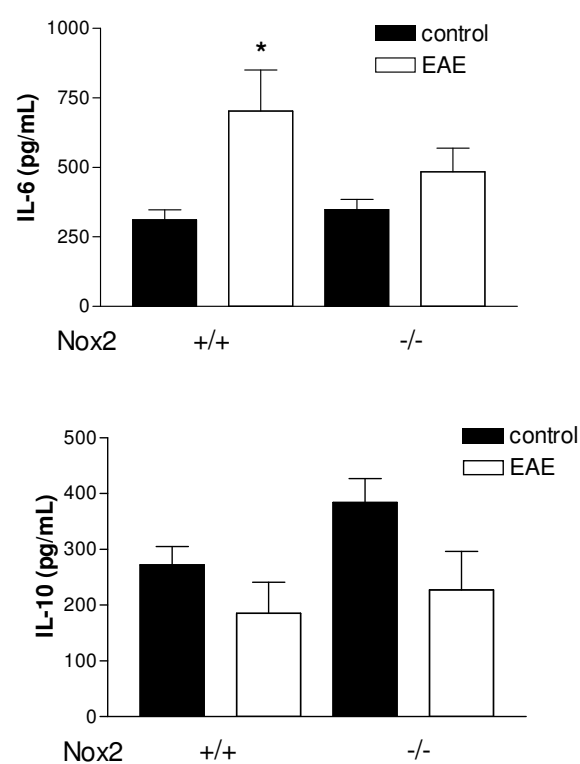

Figure 6. Effects of EAE induction on IL- 6 and IL-10 protein levels in striatum (A) and motor cortex (B) of Nox $2^{+/+}$ and Nox $2^{-/}$mice. ${ }^{*} \mathrm{p}<0.05$ and ${ }^{* *} \mathrm{p}<0.01$ vs respective control, \&p<0.05 vs Nox2 ${ }^{+/+} \mathrm{EAE}$ (Tukey's test). N=4-5. EAE: Experimental autoimmune encephalomyelitis. 
specific inhibitor of Nox2, inhibited MCP-1 release induced by LPS treatment in mice [45].

IL-10, a cytokine with potent antiinflammatory and immunosuppressive activities, has been shown to be associated with both EAE [46] and MS remission [47]. In addition, several research groups have demonstrated that IFN- $\beta$ treatment stimulates IL-10 production in MS, suggesting that IL-10 is involved in neuroprotection afforded by the treatment [48-51]. On the basis of these reports, we hypothesized that the Nox2 knockdown would increase IL-10 induction, which is in fact what we observed. IL-10 was found upregulated in the striatum of $\mathrm{Nox}^{-/}$mice at the protein and mRNA level, suggesting a role for IL-10 on the protective mechanism observed following Nox2 deletion. Similarly, Nox2 knockdown induced increased IL-10 mRNA expression in the cortex after TBI induction [52].

IL-4, another potent anti-inflammatory cytokine, is able to regulate the immune response, the production of proinflammatory cytokines and expression of major histocompatibility complex class II molecules [53]. The exogenous administration of IL-4 attenuates the disease severity after EAE induction [54]. Moreover, IL-4-deficient mice develop a more severe form of clinical disease, increased perivascular inflammation and demyelination, and increased mRNA expression of proinflammatory cytokines following EAE induction [55]. In the present study, EAE induction did not increase IL-4 expression in striatum or motor cortex of $\mathrm{Nox}^{+/+}$mice. However, Nox2 deletion significantly increased IL-4 expression in both brain structures after EAE induction. Our data suggests that IL-4 might also contribute to the improvement in clinical signs observed in $\mathrm{MOG}_{35-55}$-induced EAE in $\mathrm{Nox}^{-/}$mice. Similar results were observed following LPS-induced neuroinflammation in p47 $7^{\text {phox-I- }}$ mice. The brain levels of IL-4 as well as the mRNA expression of IL-4 receptor alpha were found increased after LPS injection in p47 $7^{\text {phox-l- }}$ when compared to $\mathrm{p} 47^{\text {phoxt/+ }}$ mice [56], suggesting a role for both Nox1 and Nox2 in LPS-induced neuroinflammation.

In summary, we have shown that Nox2 is involved in the $\mathrm{MOG}_{35-55}$-induced EAE model. Nox2 regulates cytokine mRNA levels and astrocyte activation in vivo. In addition, deletion of Nox2 leads to an improvement on EAE clinical signs and to a profound increase in the levels of the anti-inflammatory cytokines IL-4 and IL10 in brain structures affected by the disease. Both IL-4 and IL-10 are likely to be involved on the protective mechanism observed following Nox2 deletion.

\section{Ethical approval}

All procedures performed in studies involving animals were in accordance with the ethical standards of the University of Sao Paulo.

\section{Acknowledgments}

Work supported by FAPESP (Fundação de Amparo à Pesquisa do Estado de São Paulo), University of São Paulo-NAPNA (Núcleo de Apoio à Pesquisa em Neurociência Aplicada) and CNPq (Conselho Nacional de Desenvolvimento Científico e Tecnológico) and American Heart Association. Thanks are due to Adilson S. Alves for technical assistance.

\section{Conflict of interest}

The author has no conflicts of interest related to this work.

References

[1] Frischer JM, Bramow S, Dal-Bianco A, Lucchinetti CF, Rauschka $\mathrm{H}$, Schmidbauer $M$, et al. The relation between inflammation and neurodegeneration in multiple sclerosis brains. Brain. 2009;132(Pt 5):1175-89.

[2] Pierson E, Simmons SB, Castelli L, Goverman JM. Mechanisms regulating regional localization of inflammation during CNS autoimmunity. Immunol Rev. 2012;248(1):205-15.

[3] Geurts JJ, Barkhof F. Grey matter pathology in multiple sclerosis. Lancet Neurol. 2008;7(9):841-51.

[4] Constantinescu CS, Farooqi N, O'Brien K, Gran B. Experimental autoimmune encephalomyelitis (EAE) as a model for multiple sclerosis (MS). Br J Pharmacol. 2011;164(4):1079-106.

[5] Mix E, Meyer-Rienecker H, Hartung HP, Zettl UK. Animal models of multiple sclerosis--potentials and limitations. Prog Neurobiol. 2010;92(3):386-404.

[6] Bittner S, Afzali AM, Wiendl H, Meuth SG. Myelin oligodendrocyte glycoprotein (MOG35-55) induced experimental autoimmune encephalomyelitis (EAE) in C57BL/6 mice. J Vis Exp. 2014(86).

[7] Ruuls SR, Bauer J, Sontrop K, Huitinga I, t Hart BA, Dijkstra CD. Reactive oxygen species are involved in the pathogenesis of experimental allergic encephalomyelitis in Lewis rats. J Neuroimmunol. 1995;56(2):207-17.

[8] van der Goes A, Brouwer J, Hoekstra K, Roos D, van den Berg TK, Dijkstra CD. Reactive oxygen species are required for the phagocytosis of myelin by macrophages. Journal of neuroimmunology. 1998;92(12):67-75.

[9] Vladimirova O, Lu FM, Shawver L, Kalman B. The activation of protein kinase $C$ induces higher production of reactive oxygen species by mononuclear cells in patients with multiple sclerosis than in controls. Inflamm Res. 1999;48(7):412-6.

[10] Lu F, Selak M, O'Connor J, Croul S, Lorenzana C, Butunoi C, et al. Oxidative damage to mitochondrial DNA and activity of mitochondrial enzymes in chronic active lesions of multiple sclerosis. Journal of the neurological sciences. 2000;177(2):95-103.

[11] Toshniwal PK, Zarling EJ. Evidence for increased lipid peroxidation in multiple sclerosis. Neurochemical research. 1992;17(2):205-7.

[12] Greco A, Minghetti L, Sette G, Fieschi C, Levi G. Cerebrospinal fluid isoprostane shows oxidative stress in patients with multiple sclerosis. Neurology. 1999;53(8):1876-9.

[13] Ferretti G, Bacchetti T, Principi F, Di Ludovico F, Viti B, Angeleri VA, et 
al. Increased levels of lipid hydroperoxides in plasma of patients with multiple sclerosis: a relationship with paraoxonase activity. Multiple sclerosis (Houndmills, Basingstoke, England). 2005;11(6):677-82.

[14] Babior BM. NADPH oxidase: an update. Blood. 1999;93(5):1464-76.

[15] Choi BY, Kim JH, Kho AR, Kim IY, Lee SH, Lee BE, et al. Inhibition of NADPH oxidase activation reduces EAE-induced white matter damage in mice. J Neuroinflammation. 2015;12:104.

[16] Zarruk JG, Berard JL, Passos dos Santos R, Kroner A, Lee J, Arosio P, et al. Expression of iron homeostasis proteins in the spinal cord in experimental autoimmune encephalomyelitis and their implications for iron accumulation. Neurobiol Dis. 2015;81:93-107.

[17] Fischer MT, Sharma R, Lim JL, Haider L, Frischer JM, Drexhage J, et al. NADPH oxidase expression in active multiple sclerosis lesions in relation to oxidative tissue damage and mitochondrial injury. Brain. 2012;135(Pt 3):886-99.

[18] van Horssen J, Singh S, van der Pol S, Kipp M, Lim JL, Peferoen L, et al. Clusters of activated microglia in normal-appearing white matter show signs of innate immune activation. J Neuroinflammation. 2012;9:156.

[19] van der Veen RC, Dietlin TA, Hofman FM, Pen L, Segal BH, Holland SM. Superoxide prevents nitric oxide-mediated suppression of helper T lymphocytes: decreased autoimmune encephalomyelitis in nicotinamide adenine dinucleotide phosphate oxidase knockout mice. J Immunol. 2000;164(10):5177-83.

[20] Kandagaddala LD, Kang MJ, Chung BC, Patterson TA, Kwon OS. Expression and activation of matrix metalloproteinase-9 and NADPH oxidase in tissues and plasma of experimental autoimmune encephalomyelitis in mice. Exp Toxicol Pathol. 2012;64(1-2):109-14.

[21] Hernandes MS, Cafe-Mendes CC, Britto LR. NADPH oxidase and the degeneration of dopaminergic neurons in parkinsonian mice. Oxid Med Cell Longev. 2013;2013:157857.

[22] Dussault AA, Pouliot M. Rapid and simple comparison of messenger RNA levels using real-time PCR. Biol Proced Online. 2006;8:1-10.

[23] Parsa $R$, Lund $H$, Tosevski I, Zhang XM, Malipiero $U$, Beckervordersandforth $\mathrm{J}$, et al. TGFbeta regulates persistent neuroinflammation by controlling Th1 polarization and ROS production via monocyte-derived dendritic cells. Glia. 2016;64(11):1925-37.

[24] Brown DI, Griendling KK. Nox proteins in signal transduction. Free Radic Biol Med. 2009;47(9):1239-53.

[25] Chechneva OV, Mayrhofer F, Daugherty DJ, Pleasure DE, Hong JS, Deng W. Low dose dextromethorphan attenuates moderate experimental autoimmune encephalomyelitis by inhibiting NOX2 and reducing peripheral immune cells infiltration in the spinal cord. Neurobiol Dis. 2011;44(1):63-72.

[26] Wang D, Li SP, Fu JS, Zhang S, Bai L, Guo L. Resveratrol defends blood-brain barrier integrity in experimental autoimmune encephalomyelitis mice. J Neurophysiol. 2016;116(5):2173-9.

[27] Johnson DA, Amirahmadi S, Ward C, Fabry Z, Johnson JA. The absence of the pro-antioxidant transcription factor Nrf2 exacerbates experimental autoimmune encephalomyelitis. Toxicol Sci.
2010;114(2):237-46.

[28] Ravelli KG, Rosario BDA, Vasconcelos AR, Scavone C, Camarini R, Hernandes MS, et al. NADPH oxidase contributes to streptozotocininduced neurodegeneration. Neuroscience. 2017;358:227-37.

[29] Li S, Vana AC, Ribeiro R, Zhang Y. Distinct role of nitric oxide and peroxynitrite in mediating oligodendrocyte toxicity in culture and in experimental autoimmune encephalomyelitis. Neuroscience. 2011;184:107-19.

[30] . !!! INVALID CITATION !!! (Allan et al., 2014).

[31] Correale J, Farez MF. The Role of Astrocytes in Multiple Sclerosis Progression. Front Neurol. 2015;6:180.

[32] Black JA, Newcombe J, Waxman SG. Astrocytes within multiple sclerosis lesions upregulate sodium channel Nav1.5. Brain. 2010;133(Pt 3):835-46.

[33] Linker RA, Brechlin $P$, Jesse $S$, Steinacker $P$, Lee DH, Asif AR, et al. Proteome profiling in murine models of multiple sclerosis: identification of stage specific markers and culprits for tissue damage. PLoS One. 2009;4(10):e7624.

[34] Hernandes MS, D'Avila JC, Trevelin SC, Reis PA, Kinjo ER, Lopes LR, et al. The role of Nox2-derived ROS in the development of cognitive impairment after sepsis. J Neuroinflammation. 2014;11:36.

[35] Schonrock LM, Gawlowski G, Bruck W. Interleukin-6 expression in human multiple sclerosis lesions. Neurosci Lett. 2000;294(1):45-8.

[36] Stelmasiak Z, Koziol-Montewka M, Dobosz B, Rejdak K, BartosikPsujek $H$, Mitosek-Szewczyk K, et al. Interleukin-6 concentration in serum and cerebrospinal fluid in multiple sclerosis patients. Med Sci Monit. 2000;6(6):1104-8.

[37] Serada S, Fujimoto M, Mihara M, Koike N, Ohsugi Y, Nomura S, et al. IL-6 blockade inhibits the induction of myelin antigen-specific Th17 cells and Th1 cells in experimental autoimmune encephalomyelitis. Proc Natl Acad Sci U S A. 2008;105(26):9041-6.

[38] Maimone D, Gregory S, Arnason BG, Reder AT. Cytokine levels in the cerebrospinal fluid and serum of patients with multiple sclerosis. Journal of neuroimmunology. 1991;32(1):67-74.

[39] Gijbels K, Van Damme J, Proost P, Put W, Carton H, Billiau A. Interleukin 6 production in the central nervous system during experimental autoimmune encephalomyelitis. Eur J Immunol. 1990;20(1):233-5.

[40] de Jong BA, Huizinga TW, Bollen EL, Uitdehaag BM, Bosma GP, van Buchem MA, et al. Production of IL-1 beta and IL-1Ra as risk factors for susceptibility and progression of relapse-onset multiple sclerosis. J Neuroimmunol. 2002;126(1-2):172-9.

[41] Kumar A, Barrett JP, Alvarez-Croda DM, Stoica BA, Faden Al, Loane DJ. NOX2 drives M1-like microglial/macrophage activation and neurodegeneration following experimental traumatic brain injury. Brain Behav Immun. 2016;58:291-309.

[42] Van Der Voorn P, Tekstra J, Beelen RH, Tensen CP, Van Der Valk P, De Groot $C J$. Expression of MCP-1 by reactive astrocytes in demyelinating multiple sclerosis lesions. Am J Pathol. 1999;154(1):45-51.

[43] Simpson JE, Newcombe J, Cuzner ML, Woodroofe MN. Expression of monocyte chemoattractant protein-1 and other beta-chemokines by resident glia and inflammatory cells in multiple sclerosis lesions. J 
Neuroimmunol. 1998;84(2):238-49.

[44] Ransohoff RM, Hamilton TA, Tani M, Stoler MH, Shick HE, Major JA, et al. Astrocyte expression of mRNA encoding cytokines IP-10 and JE/MCP-1 in experimental autoimmune encephalomyelitis. Faseb j. 1993;7(6):592-600.

[45] Qin L, Liu Y, Hong JS, Crews FT. NADPH oxidase and aging drive microglial activation, oxidative stress, and dopaminergic neurodegeneration following systemic LPS administration. Glia. 2013;61(6):855-68.

[46] Kennedy MK, Torrance DS, Picha KS, Mohler KM. Analysis of cytokine mRNA expression in the central nervous system of mice with experimental autoimmune encephalomyelitis reveals that IL-10 mRNA expression correlates with recovery. J Immunol. 1992;149(7):2496-505.

[47] Balashov KE, Comabella M, Ohashi T, Khoury SJ, Weiner HL. Defective regulation of IFNgamma and IL-12 by endogenous IL-10 in progressive MS. Neurology. 2000;55(2):192-8.

[48] Rudick RA, Ransohoff RM, Peppler R, VanderBrug Medendorp S, Lehmann $P$, Alam J. Interferon beta induces interleukin-10 expression: relevance to multiple sclerosis. Ann Neurol. 1996;40(4):618-27.

[49] Chabot S, Yong VW. Interferon beta-1b increases interleukin-10 in a model of T cell-microglia interaction: relevance to MS. Neurology. 2000;55(10):1497-505.

[50] Wang $X$, Chen M, Wandinger KP, Williams G, Dhib-Jalbut S. IFNbeta-1b inhibits IL-12 production in peripheral blood mononuclear cells in an IL-10-dependent mechanism: relevance to IFN-beta-1b therapeutic effects in multiple sclerosis. J Immunol. 2000;165(1):54857.

[51] Byrnes AA, McArthur JC, Karp CL. Interferon-beta therapy for multiple sclerosis induces reciprocal changes in interleukin-12 and interleukin-10 production. Ann Neurol. 2002;51(2):165-74.

[52] Barrett JP, Henry RJ, Villapol S, Stoica BA, Kumar A, Burns MP, et al. NOX2 deficiency alters macrophage phenotype through an IL-10/ STAT3 dependent mechanism: implications for traumatic brain injury. J Neuroinflammation. 2017;14(1):65.

[53] Brodie C, Goldreich N, Haiman T, Kazimirsky G. Functional IL-4 receptors on mouse astrocytes: IL-4 inhibits astrocyte activation and induces NGF secretion. J Neuroimmunol. 1998;81(1-2):20-30.

[54] Racke MK, Bonomo A, Scott DE, Cannella B, Levine A, Raine CS, et al. Cytokine-induced immune deviation as a therapy for inflammatory autoimmune disease. J Exp Med. 1994;180(5):1961-6.

[55] Falcone M, Rajan AJ, Bloom BR, Brosnan CF. A critical role for IL-4 in regulating disease severity in experimental allergic encephalomyelitis as demonstrated in IL-4-deficient C57BL/6 mice and BALB/C mice. J Immunol. 1998;160(10):4822-30.

[56] Choi SH, Aid S, Kim HW, Jackson SH, Bosetti F. Inhibition of NADPH oxidase promotes alternative and anti-inflammatory microglial activation during neuroinflammation. J Neurochem. 2012;120(2):292301. 